\title{
Oxygen isotope signature during phosphite oxidation by bacterial alkaline phosphatase
}

\author{
SAE JUNG CHANG ${ }^{1 *}$ AND RUTH E. BLAKE ${ }^{2}$
}

${ }^{1}$ Seoul Center, Korea Basic Science Institute, Republic of Korea (*correspondence: sjchang15@kbsi.re.kr)

${ }^{2}$ Dept. of Geology and Geophysics, Yale University, USA

Phosphorus (P) is commonly considered to be a redox conservative element in living organisms and most $\mathrm{P}$ found in biological intermediates, including inorganic phosphate and organic phosphate esters, is fully oxidized ( +5 valence state). However, it is increasingly apparent that many organisms are capable of metabolizing reduced $\mathrm{P}$ compounds, indicating that biological P redox reactions possible and even likely. Recent discoveries have shown that Escherichia coli bacterial alkaline phosphatase (BAP), a most extensively studied enzyme for its phosphomonoesterase activity, can also catalyse the oxidation of phosphite $\left(\mathrm{PO}_{3}\right.$ with $\left.\mathrm{P}^{3+}\right)$ to phosphate $\left(\mathrm{PO}_{4}\right.$ with $\left.\mathrm{P}^{5+}\right)[1]$. We investigated the mechanisms of oxygen transfers and $\mathrm{O}$ isotopic fractionation in reactions of cell-free BAP-catalyzed $\mathrm{PO}_{3}$ oxidations using the technique of multi-labeled water isotope probing (MLWIP).

The BAP-catalyzed oxidation of phosphite was conducted using ${ }^{18} \mathrm{O}$-labeled phosphite and waters at $\mathrm{pH} 7$ and $37{ }^{\circ} \mathrm{C}$. Aqueous phosphite (13-19\%) was very slowly oxidized to phosphate over 1 year. The $\delta^{18} \mathrm{O}$ values of product phosphates varied with the $\delta^{18} \mathrm{O}$ values of ambient waters. Slopes of linear regressions of $\delta^{18} \mathrm{OPO}_{\mathrm{PO}}$ vs. $\delta^{18} \mathrm{O}_{\mathrm{H} 2 \mathrm{O}}$ data were $\sim 0.8$, which indicates that $\sim 80 \%$ of oxygen in product phosphate was derived from ambient water. Additionally, ${ }^{18} \mathrm{O}$ is preferentially incorporated into product $\mathrm{PO}_{4}$ with a fractionation of $+26 \%$. These results suggest that the BAP-catalyzed oxidation of $\mathrm{PO}_{3}$ involves at least a 2-step pathway: oxidation of $\mathrm{PO}_{3}$ to $\mathrm{PO}_{4}$ (Step 1) and, subsequent $\mathrm{O}$-isotope exchange between $\mathrm{PO}_{4}$ and water (Step 2). These results have broad implications, most notably with respect to the biochemistry of $\mathrm{P}$ redox reactions, but also with respect to the interpretation of $\mathrm{PO}_{4} \delta^{18} \mathrm{O}$ biosignatures preserved in ancient terrestrial and extraterrestrial samples, such as from Mars where reduced $\mathrm{P}$ compounds might be abundant as prebiotic $\mathrm{P}$ sources under an oxygenfree environment.

[1] Yang \& Metcalf (2004) PNAS 101, 7919.

[2] Herschy et al. (2018) Nature Communications 9, 1346. 